\title{
Protective effect of cactus cladode extract against cisplatin induced oxidative stress, genotoxicity and apoptosis in balb/c mice: combination with phytochemical composition
}

Dalel Brahmi ${ }^{1,2}$, Yousra Ayed ${ }^{1}$, Mbarka Hfaiedh² $^{2}$ Chayma Bouaziz ${ }^{1}$, Hedi Ben Mansour ${ }^{3}$, Lazhar Zourgui ${ }^{2,4}$ and Hassen Bacha ${ }^{1,5^{*}}$

\begin{abstract}
Background: Cis-Platinum (II) (cis-diammine dichloroplatinum; CDDP) is a potent antitumor compound widely used for the treatment of many malignancies. An important side-effect of CDDP is nephrotoxicity. The cytotoxic action of this drug is often thought to induce oxidative stress and be associated with its ability to bind DNA to form CDDP-DNA adducts and apoptosis in kidney cells. In this study, the protective effect of cactus cladode extract (CCE) against CDDP-induced oxidative stress and genotoxicity were investigated in mice. We also looked for levels of malondialdehyde (MDA), catalase activity, superoxide dismutase (SOD) activity, chromosome aberrations (CA) test, SOS Chromotest, expressions of p53, bax and bcl2 in kidney and we also analyzed several parameters of renal function markers toxicity such as serum biochemical analysis.

Methods: Adult, healthy balb/c (20-25 g) male mice aged of 4-5 weeks were pre-treated by intraperitonial administration of CCE $(50 \mathrm{mg} / \mathrm{Kg} . \mathrm{b} . \mathrm{w})$ for 2 weeks. Control animals were treated 3 days a week for 4 weeks by intraperitonial administration of $100 \mu \mathrm{g} / \mathrm{Kg}$.b.w CDDP. Animals which treated by CDDP and CCE were divided into two groups: the first group was administrated CCE 2 hours before each treatment with CDDP 3 days a week for 4 weeks. The second group was administrated without pre-treatment with CCE but this extract was administrated 24 hours after each treatment with CDDP 3 days a week for 4 weeks.

Results: Our results showed that CDDP induced significant alterations in all tested oxidative stress markers. In addition it induced CA in bone morrow cells, increased the expression of pro-apoptotic proteins p53 and bax and decreased the expression of anti-apoptotic protein bcl2 in kidney. On the other hand, CDDP significantly increased the levels of urea and creatinine and decreased the levels of albumin and total protein. The treatment of CCE before or after treatment with CDDP showed, (i) a total reduction of CDDP induced oxidative damage for all tested markers, (ii) an anti-genotoxic effect resulting in an efficient prevention of chromosomal aberrations compared to the group treated with CDDP alone (iii) restriction of the effect of CDDP by differential modulation of the expression of p53 which is decreased as well as its associated genes such as bax and bcl2, (iiii) restriction of serums levels of creatinine, urea, albumin and total protein resuming its values towards near normal levels of control.
\end{abstract}

Conclusion: We concluded that CCE is beneficial in CDDP-induced kidney dysfunction in mice via its anti-oxidant anti-genotoxic and anti-apoptotic properties against CDDP.

Keywords: Cactus, CDDP, Genotoxicity, Antioxidant, Protective effect

\footnotetext{
* Correspondence: hassen.bacha@fmdm.rnu.tn

'Laboratory of Research on Biologically Compatible Compounds, Faculty of

Dentistry, Rue Avicenne, 5019, Monastir, Tunisia

${ }^{5}$ University of Jendouba, Jendouba, Tunisia

Full list of author information is available at the end of the article
} 


\section{Background}

CDDP (cis-dichlorodiammineplatinum (II), CDDP) is a synthetic anticancer drug extensively used clinically for the treatment of several human malignancies such as ovarian, testicular, bladder, head and neck, and uterine cervix carcinomas [1-3]. Various data indicate that CDDP induces oxidative stress, lipid peroxides [4] and DNA damage [5,6]. Also, there is evidence suggesting that the generation of free radicals causes nephrotoxic effects by CDDP $[7,8]$. There is a continuous search for agents that provide nephroprotection against CDDP and other platinum drugs; these include antioxidants, modulators of nitric oxide, diuretics, and cytoprotective and apoptotic agents [9]. However, none of these were found to be suitable/safe for clinical use in protecting against CDDP-induced nephrotoxicity.

In the past few years, much interest has been centered on the role of naturally occurring dietary substances for the control and management of various chronic diseases $[10,11]$ such as cactus Opuntia ficus indica which grows all over the semiarid countries and is mainly cultivated for its fruit (cactus pear) and cladode which are rich in nutritional compounds [12]. In Chinese medicine cactus pear is used against inflammation and snakebite [13]. Different parts of Opuntia ficus-indica are used in the traditional medicine in several countries: the cladodes are utilized to reduce serum cholesterol level and blood pressure, for treatment of ulcers, rheumatic pain and kidney conditions [14]. The fruits have shown antiulcerogenic [15] and neuroprotective activity [16].

But a few studies have examined the cytoprotective effect of cladodes that is why we chose CCE against toxicity of CDDP.

Taking into consideration the potential clinical use of CDDP and the numerous health benefits of CCE. The aim of the present study was to find out the eventual protective effect of CCE against CDDP-induced oxidative stress and genotoxicity and nephrotoxicity in vivo using balb/c mice. We evaluated the antioxidant and antigenotoxic potential CCE against CDDP. To this end we also measured (i) levels of MDA, level of catalase and SOD activity, evaluated (ii) chromosome aberrations, p53, bax and bcl2 protein expressions we also analyzed several parameters of renal function markers toxicity. It is also of interest to find whether there is any correlation between total phenolic and total flavonoid contents of plant extract and the different activities.

\section{Methods}

\section{Chemicals}

CDDP salt (cis-diamineplatinum (II) dichloride, CAS no. 15663-27-1) was purchased from Sigma-Aldrich Chemical Co. (St. Louis, MO, USA). It was dissolved in water. Nitro blue tetrazolium (NBT) and 5-bromo-4-chloro-3- indolyl phosphate disodium salt (BCIP) were from Sigma Aldrich, France. Mouse monoclonal anti-p53, anti-bax and anti-bcl 2 and the secondary antibody (phosphataseconjugated) were from Invitrogen. All other chemicals used were of the highest grade available from commercial sources.

\section{Extract of cactus cladodes}

Young cactus cladodes of Opuntia ficus-indica (2-3 weeks of age) collected from the local area were washed with water chopped into small pieces and then pressed using a hand-press, homogenized with $10 \mathrm{mM}$ Tris$\mathrm{HCl}, \mathrm{pH} 7.4$ at $4^{\circ} \mathrm{C}$ and centrifuged $30 \mathrm{~min}$ at $3500 \mathrm{~g}$ at $4^{\circ} \mathrm{C}$. The supernatant was collected and lyophilized. Prior to use, the lyophilized extract was dissolved in water.

\section{Determination of total polyphenol and flavonoid contents}

The polyphenol content of CCE was quantified by the Folin-Ciocalteau reagent $[17,18]$. Aliquots of test samples $(100 \mu \mathrm{l})$ were mixed with $2.0 \mathrm{ml}$ of $2 \% \mathrm{Na} 2 \mathrm{CO} 3$ and incubated at room temperature for $2 \mathrm{~min}$. After the addition of $100 \mu \mathrm{l} \quad 50 \%$ Folin-Ciocalteau phenol reagents, the reaction tube was further incubated for $30 \mathrm{~min}$ at room temperature, and finally absorbance was read at $720 \mathrm{~nm}$. Gallic acid $(0.2 \mathrm{mg} / \mathrm{ml})$ was used as a standard. Polyphenol content was expressed according to the following formula:

$$
\% \text { Polyphenols }=\left(\frac{\frac{\left(\mathrm{DO}_{\text {extract }} \times 0.2\right)}{\mathrm{DO}_{(\text {Gallicacid })}}}{\text { Extract } \text { concentration }}\right) \times 100
$$

A known volume of extract was placed in a $10-\mathrm{ml}$ volumetric flask to estimate flavonoid content according to the modified method of Zhishen et al. (1999) [19]. After addition of $75 \mu \mathrm{l}$ of NaNO2 (5\%), $150 \mu \mathrm{l}$ of freshly prepared $\mathrm{AlCl} 3(10 \%)$, and $500 \mu \mathrm{l}$ of $\mathrm{NaOH}(1 \mathrm{~N})$, the volume was adjusted with distilled water until $2.5 \mathrm{ml}$. After 5 min incubation, the total absorbance was measured at $510 \mathrm{~nm}$. Quercetin $(0.05 \mathrm{mg} / \mathrm{ml})$ was used as a standard compound. Flavonoid content was expressed according to the following formula:

$$
\% \text { Flavonoids }=\left(\frac{\frac{\mathrm{DO}_{\text {extract }} \times 0.05}{\mathrm{DO}_{\text {Quercetin }}}}{\text { Extract concentration }}\right) \times 100
$$

\section{Determination of tannin content}

The method described by Pearson, (1976) [20] was used for the determination of tannin content of samples. Extraction of tannin from the samples was achieved by dissolving $5 \mathrm{~g}$ of each sample in $50 \mathrm{ml}$ of distilled water in a conical flask, allowing the mixture to stand for $30 \mathrm{~min}$ 
with shaking the flask at 10 min intervals, and then centrifuging at $5000 \mathrm{~g}$ to obtain a supernatant (tannin extract). The extract was diluted to $100 \mathrm{ml}$ in a standard flask using distilled water. $5 \mathrm{ml}$ of the diluted extract and $5 \mathrm{ml}$ of standard tannic acid $(0.1 \mathrm{~g} / \mathrm{l})$ were measured into $50 \mathrm{ml}$ volumetric flask. $1 \mathrm{ml}$ of Folin-Denis reagent was added to each flask followed by $2.5 \mathrm{ml}$ of saturated sodium carbonate solution. The solutions were made up to the $50-\mathrm{ml}$ mark with distilled water and incubated at room temperature $\left(20-30^{\circ} \mathrm{C}\right)$ for $90 \mathrm{~min}$. The absorption of these solutions was measured against that of the reagent blank (containing $5 \mathrm{ml}$ distilled water instead of extract or standard tannic acid solution) in a Genesys (Wisconsin USA) spectrophotometer at $760 \mathrm{~nm}$ wavelength. Tannin content determination assay was tested in triplicate and calculated according to the following formula [21]:

$$
\% \text { Tannins }=\frac{\frac{\mathrm{DO}_{\text {extract }}}{\epsilon \times 1}}{\text { Extract concentration }} \times 100
$$

where $\epsilon$ : molar extinction coefficient $\left(\mathrm{g} \mathrm{g}^{-1} \mathrm{~cm}^{-1}\right)$ of tannic acid $\left(3.27 \mathrm{~L} \mathrm{~g}^{-1} \mathrm{~cm}^{-1}\right)$.

\section{$D P P H$ radical scavenging assay}

Radical scavenging activity (RSA) of the CCE was measured using the free radical $\alpha, \alpha$-diphenyl-b-picrylhydrazyl (DPPH) [22]. According to the method, $0.1 \mathrm{~g}$ of the sample was extracted in $2.9 \mathrm{ml}$ of methanol by centrifuging at $5000 \mathrm{rpm}$ for $15 \mathrm{~min}$. The content was filtered through Whatman No.1 filter paper. Methanolic DPPH $(0.5 \mathrm{ml}$, $500 \mu \mathrm{M})$ was added to the tubes containing this supernatant and shaken vigorously. The tubes were incubated at room temperature for $45 \mathrm{~min}$ in the darkness. Vitamin $\mathrm{E}$ was used as a reference compound in the same concentration range as the test compounds.

The changes in optical density (OD) of the samples were measured at $515 \mathrm{~nm}$ with methanol as blank. RSA was expressed as the percentage inhibition of DPPH radical and calculated using the following formula:

$$
\begin{gathered}
\% \text { Radical scavenging activity }(\mathrm{DPPH}) \\
=\frac{(\text { Control OD }- \text { Sample OD })}{\text { Control OD }} \times 100
\end{gathered}
$$

When DPPH reacts with an antioxidant compound, which can donate hydrogen, it is reduced. The changes in colour (from deep-violet to light-yellow) were measured at $515 \mathrm{~nm}$ on a UV/visible light spectrophotometer (Spectronic Genesys).

\section{Animals and treatments}

Adult, healthy balb/c (20-25 g) male mice aged of 4-5 weeks provided from an animal breeding centre (SEXAL St. Doulchard, France following the agreement of the Ethics Committee named National committee of Medical ethics CNEM, BP 74 - Pasteur Institute Tunis 1002 TUNISIA) were used. The animals were kept for acclimatization 1 week under constant conditions of temperature and a light/dark cycle of $12 \mathrm{~h}: 12 \mathrm{~h}$. Animals had free access to standard granulated chow and drinking water.

All animals were divided in 8 groups of 6 animals per group and treated as follows:

Group 1: Mice given $\mathrm{H} 2 \mathrm{O}(100 \mu \mathrm{l})$ by intraperitonial route (ip)

Group 2: Mice given CCE $50 \mathrm{mg} / \mathrm{Kg}$ b.w (ip) for 45 days.

Group 3: Mice given CDDP $100 \mu \mathrm{g} / \mathrm{Kg}$ b.w for 15 days treatment.

Group 4: Mice are pre-treated with only CCE for 15 days and they given CDDP $100 \mu \mathrm{g} / \mathrm{Kg}$ b.w + CCE $50 \mathrm{mg} / \mathrm{Kg}$ b.w for other 15 days (second treatment with CCE is before 2 hours injection with CDDP).

Group 5: Mice are pre-treated with only CCE for 15 days and they given CDDP $100 \mu \mathrm{g} / \mathrm{Kg}$ b.w $+\mathrm{CCE}$ $50 \mathrm{mg} / \mathrm{Kg}$ b.w for other 15 days (second treatment with CCE is after 24 hours injection with CDDP). NB: Groups 6, 7 and 8 are not pre-treated with CCE

Group 6: Mice given CDDP $100 \mu \mathrm{g} / \mathrm{Kg}$ b.w for 30 days treatment

Group 7: Mice given CDDP $100 \mu \mathrm{g} / \mathrm{Kg}$ b.w + CCE $50 \mathrm{mg} / \mathrm{Kg}$ b.w (before 2 hours injection with CDDP for 30 days treatment)

Group 8: Mice given CDDP $100 \mu \mathrm{g} / \mathrm{Kg}$ b.w + CCE $50 \mathrm{mg} / \mathrm{Kg}$ b.w (after 24 hours injection with CDDP for 30 days treatment).

At the end of the experiment, animals were sacrificed under light ether anesthesia by decapitation and the kidneys were immediately removed.

\section{Evaluation of lipid peroxidation status}

Lipid peroxidation was determined indirectly by measuring the production of MDA in the renal extracts following the method of Aust et al. (1985) [23]. Briefly, $200 \mu \mathrm{l}$ of kidney extracts were mixed with $150 \mu \mathrm{l}$ of TBS (Tris $50 \mathrm{mM}$ and $\mathrm{NaCl} 150 \mathrm{mM}, \mathrm{pH}$ 7.4) and $250 \mu \mathrm{l}$ TCABHT (20\% TCA and BHT 1\%). The mixture was vigorously vortexed and centrifuged at $1500 \mathrm{~g}$ for $10 \mathrm{~min}$. $400 \mu$ of the supernatant were added with $\mathrm{HCl} 0.6 \mathrm{~N}$ and $320 \mu \mathrm{l}$ Tris-TBA (Tris $26 \mathrm{mM}$ and TBA $120 \mathrm{mM}$ ), the content was mixed and incubated $10 \mathrm{~min}$ at $80^{\circ} \mathrm{C}$. The absorbance was measured at $535 \mathrm{~nm}$. The optic density corresponding to the complex formed with the TBA-MDA is proportional to the concentration of MDA and to the lipid peroxide. The concentration of $\mu \mathrm{mol}$ of $\mathrm{MDA} / \mathrm{mg}$ of proteins is calculated from the 
absorbance at $530 \mathrm{~nm}$ using the molar extinction coefficient of MDA $1.56 \times 10^{5} \mathrm{M}^{-1} \mathrm{~cm}^{-1}$.

\section{Determination of catalase activity}

Catalase activity was measured in the kidney extracts at $240 \mathrm{~nm}$, according to Clairbone (1985) [24]. Briefly, $20 \mu \mathrm{l}$ of the extracts were added in the quartz cuvette contain $780 \mu \mathrm{l}$ phosphate buffer and $200 \mu \mathrm{l}$ of $\mathrm{H}_{2} \mathrm{O}_{2} 0.5 \mathrm{M}$. The activity of catalase was calculated using the molar extinction coefficient $\left(0.04 \mathrm{Mm}^{-1} \mathrm{~cm}^{-1}\right)$. The results were expressed as $\mu \mathrm{mol}$ of $\mathrm{H}_{2} \mathrm{O}_{2} / \mathrm{min} / \mathrm{mg}$ of proteins.

\section{Determination of SOD activity}

Kidney tissue was homogenized with 10 volumes of icecold $1.15 \% \mathrm{KCl}$ buffer containing 0.4 Mm PMSF and was centrifuged at $2000 \mathrm{rpm}$ for $10 \mathrm{~min}\left(4^{\circ} \mathrm{C}\right)$. Total $(\mathrm{Cu}-\mathrm{Zn}$ and $\mathrm{Mn}) \mathrm{SOD}$ activity was determined according to Sun et al. (1988) [25]. The method is based on the inhibition of nitro blue tetrazolium (NBT) reduction by the xanthine-xanthine oxidase system as a superoxide generator. One unit of SOD was defined as the enzyme amount causing $50 \%$ inhibition in the NBT reduction rate. SOD activity was also expressed as units per milligram protein (U/mg protein).

\section{Chromosome aberration assay}

24 hours before sacrifice, animals were given a suspension of yeast powder $(100 \mathrm{mg} / 500 \mu \mathrm{l})$ to accelerate mitosis of bone-marrow cells. Vinblastine $(200 \mu \mathrm{l} ; 250 \mu \mathrm{g} / \mathrm{ml})$ was injected into the animals 45 min before sacrifice in order to block dividing cells in metaphasis. Bone-marrow cells from femurs and tibias were collected, subjected to hypotonic shock $(\mathrm{KCl} 0.075 \mathrm{M})$ and fixed three times using methanol-acetic acid [26]. The cells were spread on glass slides that were blazed on a flame for $5 \mathrm{~s}$, then air-dried for conservation at room temperature and finally stained by $4 \%$ dilution of Giemsa reagent in water for $15 \mathrm{~min}$. After coding of the slides, the chromosomes of 100 cells in metaphase were examined for abnormalities at a magnification of 1000x using an optical microscope (Carl Zeiss, Germany). This was done for each one of three replicates (300 metaphases per dose level) for negative controls, positive controls and treated groups. Chromosome aberrations were identified according to criteria described by Savage (1975) [27]. Metaphases with chromosome breaks, gaps, rings and centric fusions (robertsonian translocation) were recorded and expressed as percentage of total metaphases per group.

\section{Activation mixture}

The S9 microsome fraction was prepared from the liver of rats treated with Aroclor 1254 [28]. The composition of the activation mixture is the following per $10 \mathrm{ml}$ of $\mathrm{S} 9$ mix: salt solution $\left(1.65 \mathrm{M} \mathrm{KCl}+0.4 \mathrm{M} \mathrm{MgCl} 26 \mathrm{H}_{2} \mathrm{O}\right)$
$0.2 \mathrm{ml}$; G6P $(1 \mathrm{M}) 0.05 \mathrm{ml}$; NADP $(0.1 \mathrm{M}) 0.15 \mathrm{ml}$; Tris buffer (0.4 M pH7.4) $2.5 \mathrm{ml}$; Luria broth medium $6.1 \mathrm{ml}$; S9 fraction $1 \mathrm{ml}$.

\section{Sos chromotest}

The SOS chromotest assay is a bacterial test for detecting DNA damaging agent. It was employed to determine the effect of cactus cladode extract on the genotoxicity of aflatoxin B1 (direct acting mutagen) induced genotoxicity. The SOS chromotest with Escherichia coli PQ37strain was performed according to the procedure described by Quillardet and Hofnung (1985) [29]. The genotype of this strain is: F-thr leu his-4 pyrD thi galE galK lacDU169 Srl300 Tn10 rpoB rpsL uvrA rfa trp Muc + sfiA::Mud (Ap, lac) cts. An exponential-phase culture of E. coli PQ37 was grown at $37^{\circ} \mathrm{C}$ in $\mathrm{LB}$ medium to an approximate cell density of $2.10^{8} \mathrm{cell} / \mathrm{ml}$ supplemented with ampicillin $(20 \mu \mathrm{g} / \mathrm{ml})$. One $\mathrm{ml}$ of this culture was diluted with $9 \mathrm{ml}$ of fresh medium; Positive controls were prepared by exposure of the bacteria to CDDP. After $2 \mathrm{~h}$ of incubation at $37^{\circ} \mathrm{C}$, with shaking, $300 \mu \mathrm{l}$ samples were used for assaying $\beta$-galactosidase $(\beta$-gal) and alkaline phosphatase (AP) activities. In this assay, the $\beta$-galactosidase synthesis (lacZ gene) is dependent on sfiA activation and is used to measure induction of SOS repair system. The activity of the constitutive enzyme alkaline phosphatase was used as a measure of protein synthesis and toxicity. Enzyme activities were assessed spectrophotometrically. The SOS induction factor (IF) in treated cells was obtained by comparing $\beta$-galactosidase and alkaline phosphatase activities in treated and untreated cells. The result was considered positive when the IF for $\beta$-galactosidase activity was $>2.0$. For evaluation of the protective effect of CCE on the induction of the SOS response by CDDP (in the presence of the S9 activation mixture), $10 \mu \mathrm{l}$ of CDDP $(10 \mu \mathrm{g} /$ assay $)$ were added into tubes with $10 \mu \mathrm{l}$ of the tested concentration of CCE. Antigenotoxicity was expressed as percentage inhibition of genotoxicity induced by CDDP according to the formula:

$$
\%: 100-\left(\mathrm{IF} 1-\frac{\mathrm{IF} 0}{\mathrm{IF} 2}-\mathrm{IF} 0\right){ }^{*} 100
$$

where IF1 is the induction factor in the presence of the test compound and the genotoxin, IF2 the induction factor in the absence of the test compound and in the presence of the genotoxin, and IF0 is the induction factor of the negative control. Data were collected as a mean \pm S.D. of experiments.

\section{Protein extraction and Western blot analysis}

Equal amounts of proteins $(20 \mu \mathrm{g})$ were separated by $12 \%$ SDS-polyacrylamide gel electrophoresis. Separated 
Table 1 Quantitative polyphenols, flavonoids and tannins of cactus cladode extract

\begin{tabular}{lc}
\hline Metabolites & Cactus cladode extract \\
\hline Total polyphenols $\mu \mathrm{g}$ (Gallic acid equivalents) & $600,18 \pm 6,1$ \\
\hline Flavonoids $\mu \mathrm{g}$ (Quercetin equivalents) & $223,04 \pm 2,2$ \\
\hline Tannins $\mu \mathrm{g}$ (Tannic acid equivalent) & $53,33 \pm 0,5$ \\
\hline
\end{tabular}

proteins were electro-blotted on nitrocellulose membrane in the transfer buffer (10 ml Tris-base, $\mathrm{pH} \mathrm{8.3,}$ $96 \mathrm{mM}$ glycine and $10 \%$ methanol). The membrane was then blocked in TBS (20 mM Tris- $\mathrm{HCl}, \mathrm{Ph} 7.5,500 \mathrm{mM}$ sodium chloride) containing $5 \%$ of BSA, washed in TBS (TBS containing $0.3 \%$ Tween 20) and probed with an antibody for $\mathrm{p} 53$ or bax or bcl2 at a 1:1000 dilution for $6 \mathrm{~h}$ at room temperature. The membrane was then washed and incubated with goat anti-mouse alkaline phosphate conjugated at a 1:3000 dilution for $1 \mathrm{~h}$. Next, the membrane was washed and the chromogenic substrate BCIP/NBT was added to localize antibody binding. P53, bax and bcl2 levels were then determined by computer-assisted densitometric analysis (Densitometer, GS-800, BioRad Quantity One).

\section{Biochemical assay}

Creatinine, urea were performed spectrophotometrically using an autoanalyzer (Opera, Techicon, Bayer, USA). Total protein was determined in plasma samples by the Biuret method according to Gornall et al. (1949) [30].

Albumin concentration was determined by the method of Doumas et al. (1977) [31].

\section{Statistical analysis}

Experimental values are expressed as mean \pm SD. Comparison of mean values between groups was performed by one way-analysis of variance (oneway-ANOVA) followed by post- hoc Tukey test. Expression of p53, bax and bcl 2 were determined by Kruskal-Wallis Test. The level of significance was accepted with $\mathrm{P}<0.05$ was used for statistical analysis.

\section{Results}

Preliminary phytochemical analysis

Determination of total polyphenol, flavonoid and tannin contents

The phytochemical study of CCE showed the presence of various quantities of polyphenols, flavonoids and tannins (Table 1). Ours results showed that $1 \mathrm{mg}$ of cladode extract was equivalent to $600 \mu \mathrm{g}$ of gallic acid, $223 \mu \mathrm{g}$ of quercetin and $53 \mu \mathrm{g}$ of tannic acid.

\section{Radical-scavenging activities}

The radical scavenging activity was evaluated by the $\mathrm{DPPH}$ assay. DPPH is a molecule containing a stable free radical; In the presence of an antioxidant that can donate an electron to DPPH, the purple color typical of the free DPPH radical decays, a change that can be followed spectrophotometrically at $517 \mathrm{~nm}$. This simple test can provide information on the ability of a compound to donate an electron, the number of electrons a given molecule can donate, and on the mechanism of antioxidant action.

The radical-scavenging activity of CCE, measured as decolorizing effect following the trapping of the unpaired electron of DPPH, is shown in Figure 1. The CCE has a potent radical scavenger with a percentage decrease versus the absorbance of DPPH standard solution of $76.11 \%$.

\section{Effect of CCE on oxidative stress induced by CDDP Evaluation of lipid peroxidation status}

Animals were injected with CDDP $(100 \mu \mathrm{g} / \mathrm{kg}$ (b.w)) to investigate the lipid peroxidation; Results of the effect of CDDP alone and jointly with CCE on the induction of

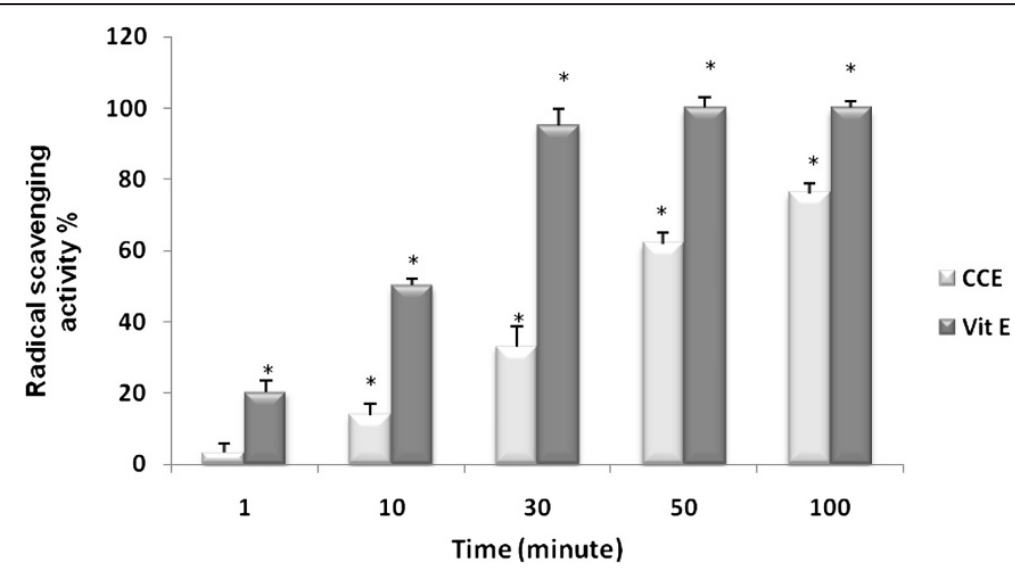

Figure 1 Radical scavenging activity of CCE by DPPH method. CCE and vitamin E (Vit E), ${ }^{*} p<0.05$. 


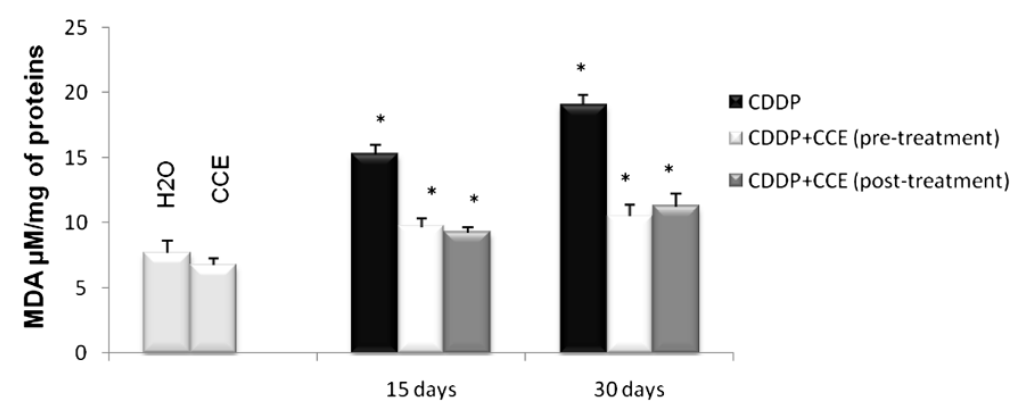

Figure 2 Lipid peroxydation as determined by MDA level in kidney of balb/c mice exposed to CDDP (100 $\mu \mathrm{g} / \mathrm{Kg}$ b.w) for 15 days then 30 days and prevention by CCE $(50 \mathrm{mg} / \mathbf{K g}$ b.w) before or after CDDP administration. Results were expressed as means \pm S.D. from independent experiments. Significantly different $p<0.05$. * indicated significant difference $(p<0.05)$ from control. For 15 days of treatment: Mice given CDDP $100 \mu \mathrm{g} / \mathrm{Kg}$ b.w or Mice given CDDP $100 \mu \mathrm{g} / \mathrm{Kg}$ b.w + CCE 50 mg/Kg b.w (pre-treatment) and Mice given CDDP $100 \mu \mathrm{gg} / \mathrm{Kg}$ b.w + CCE $50 \mathrm{mg} / \mathrm{Kg}$ b.w (post-treatment). For 30 days of treatment: Mice given CDDP $100 \mu \mathrm{g} / \mathrm{Kg}$ b.w or Mice given CDDP $100 \mu \mathrm{gg} / \mathrm{Kg}$ b.w + CCE $50 \mathrm{mg} / \mathrm{Kg}$ b.w (pre-treatment) and Mice given CDDP $100 \mu \mathrm{g} / \mathrm{Kg}$ b.w + CCE $50 \mathrm{mg} / \mathrm{Kg}$ b.w (post-treatment).

lipid peroxidation in kidney as determined by MDA level are shown in Figure 2, after 15 days of exposure, MDA levels increased significantly in kidney extracts of mice treated with CDDP $(15.25 \pm 0.30 \mathrm{nmol} / \mathrm{ml})$, on days 30 , MDA levels is $(19.03 \pm 0.12 \mathrm{nmol} / \mathrm{ml})$ compared with the control value $(7.68 \pm 0.15 \mathrm{nmol} / \mathrm{ml})$. However, the pre or post-treatment with CCE $(50 \mathrm{mg} / \mathrm{kg}$ b.w) before or after treatment with CDDP induced a sharp decrease in MDA level was noticed in both times 15 days and 30 days, MDA level has decreased significantly to reach the control level.

\section{Determination of catalase activity}

Figure 3 illustrates the effect of CDDP and CCE on catalase activity. CDDP induced a marked decrease in catalase activity after 15 days and 30 days exposure on kidney extracts at day 30 lowest level of catalase activity was observed by $25,3 \mathrm{U} / \mathrm{mg}$ protein, but both before and after CDDP exposure the CCE striking increase of this activity was noticed and duplicated in kidney with CCE treatment.

\section{Determination of SOD activity}

Figure 4 illustrates the effect of CDDP and CCE on SOD activity, CDDP induced a marked decrease in SOD activity after 15 days and 30 days exposure on kidney extracts by $0.056 \mathrm{U} / \mathrm{mg}$ proteins at 30 days of CDDP treatment, but the pre and post-treatment by CCE increase significantly the level of SOD activity to reach the control level.

\section{Effect of CCE on DNA damage induced by CDDP Eventual prevention of CDDP-induced chromosome aberrations by CCE}

Genotoxicity of CDDP was assessed through test of chromosome aberrations in mice bone marrow cells. Results of the visual scoring of total DNA damage induced by CDDP are shown in Figure 5 . We observed that animals treated with CDDP alone $(100 \mu \mathrm{g} / \mathrm{kg} \mathrm{b.w})$ showed a significant increase in chromosome aberrations in bone marrow cells especially on day 30 with $42 \%$ of chromosome aberrations. Control groups which were treated with $\mathrm{H}_{2} \mathrm{O}$, or CCE showed a similar basal

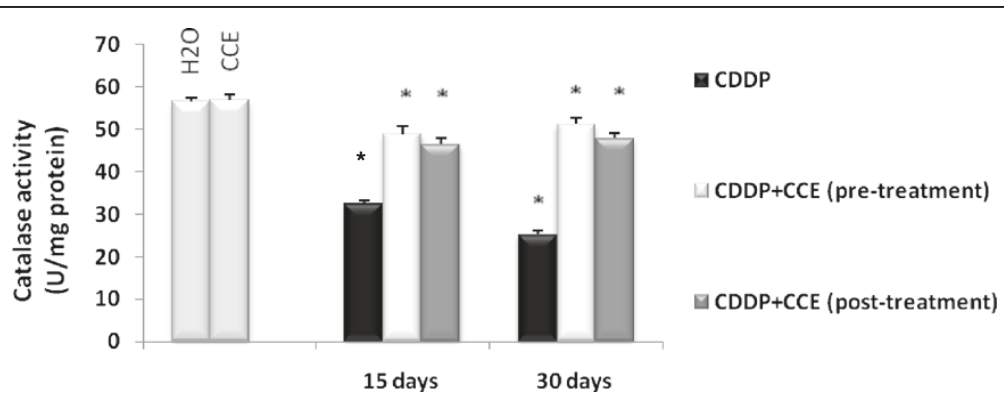

Figure 3 Effect of CCE $(50 \mathrm{mg} / \mathrm{Kg} \mathrm{b.w})$, before and after treatment by CDDP (100 $\mu \mathrm{g} / \mathrm{Kg} \mathrm{b.w})$ induced catalase enzyme activity in mice. Significantly different, $p<0.05$. Results were expressed as means \pm S.D. *indicated significant difference $(p<0.05)$ from control. For 15 days of treatment: Mice given CDDP $100 \mu \mathrm{g} / \mathrm{Kg}$ b.w or Mice given CDDP $100 \mu \mathrm{g} / \mathrm{Kg}$ b.w + CCE $50 \mathrm{mg} / \mathrm{Kg}$ b.w (pre-treatment) and Mice given CDDP

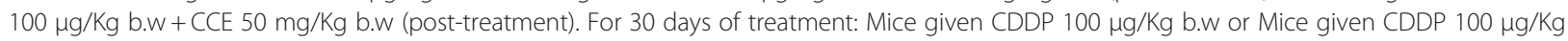
b.w + CCE $50 \mathrm{mg} / \mathrm{Kg}$ b.w (pre-treatment) and Mice given CDDP $100 \mu \mathrm{g} / \mathrm{Kg}$ b.w + CCE $50 \mathrm{mg} / \mathrm{Kg}$ b.w (post-treatment). 


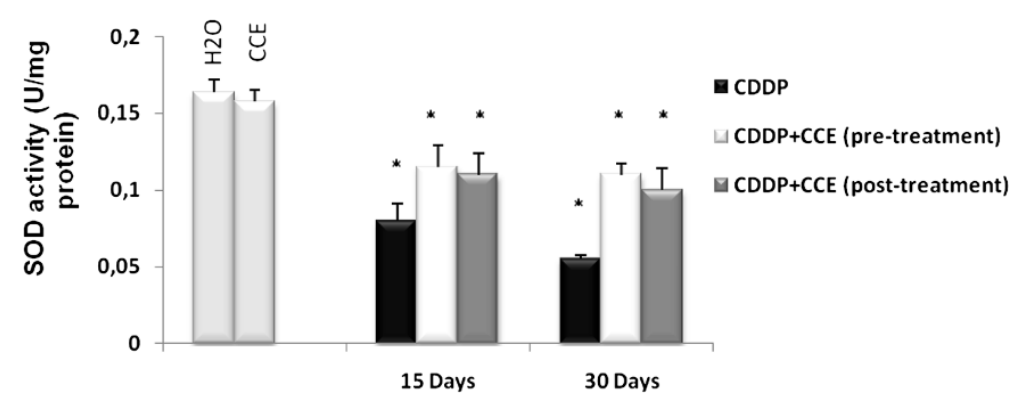

Figure 4 Effect of CCE (50 mg/Kg b.w), before and after treatment by CDDP (100 $\mu \mathrm{g} / \mathrm{Kg} \mathrm{b.w})$ induced SOD enzyme activity in mice. Significantly different, $p<0.05$. Results were expressed as means \pm S.D. * indicated significant difference $(p<0.05)$ from control. For 15 days of treatment: Mice given CDDP $100 \mu \mathrm{g} / \mathrm{Kg}$ b.w or Mice given CDDP $100 \mu \mathrm{g} / \mathrm{Kg}$ b.w +CCE $50 \mathrm{mg} / \mathrm{Kg}$ b.w (pre-treatment) and Mice given CDDP

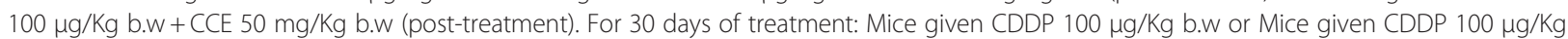
b.w + CCE 50 mg/Kg b.w (pre-treatment) and Mice given CDDP $100 \mu \mathrm{g} / \mathrm{Kg}$ b.w + CCE $50 \mathrm{mg} / \mathrm{Kg}$ b.w (post-treatment).

and low percentage of total chromosome aberrations (respectively $3.78 \pm 1.5$ and $3.67 \pm 1.78$ ). But we remarked that the co-administration of cactus before or after CDDP treatment decreased significantly the total chromosomal aberrations.

\section{The SOS chromotest assay}

Experiments realized with CCE revealed no genotoxicity induction in so far as the induction factor is not higher than 1.5. While experiment with CDDP give the maximum of genotoxicity with IF $=3.24$ similar to genotoxic effect of aflatoxin B1considered a positive control of genotoxicity with IF $=4.24$. The inhibitory effect of the tested product on the genotoxicity induced by CDDP using the SOS chromotest is illustrated by Table 2 . This study shows that CCE present an antigenotoxic effect at the tested concentrations. Indeed CCE treatment significantly decreases the IF of CDDP by $58 \%$.

\section{Effect of CCE on apoptosis status Determination of $p 53$ expression}

Figure $6 \mathrm{a}$ and $6 \mathrm{~b}$ showed the Western blotting and densitometry analysis of p53 expression in kidney of controls and treated animals. After 15 days and 30 days exposure to CDDP alone, p53 expression was found to be significantly increased compared to controls but it decreased by CCE pre or post-treatment. The CCE treated group did not have any significant effect on the expression of p53 (Additional file 1).

\section{Determination of bax expression}

CDDP induces the expression of bax genes in kidney as evidenced by example of immunoblotting illustrated in Figure $7 \mathrm{a}$, which was further, confirmed by results of scanning densitometry (Figure $7 \mathrm{~b}$ ). The administration of CCE before and after CDDP exposure for 15 and 30 days treatment decreased the amounts of bax (Figure $7 \mathrm{a}$ and $7 \mathrm{~b}$ ). The CCE treated group did not have any significant effect on the expression of bax.

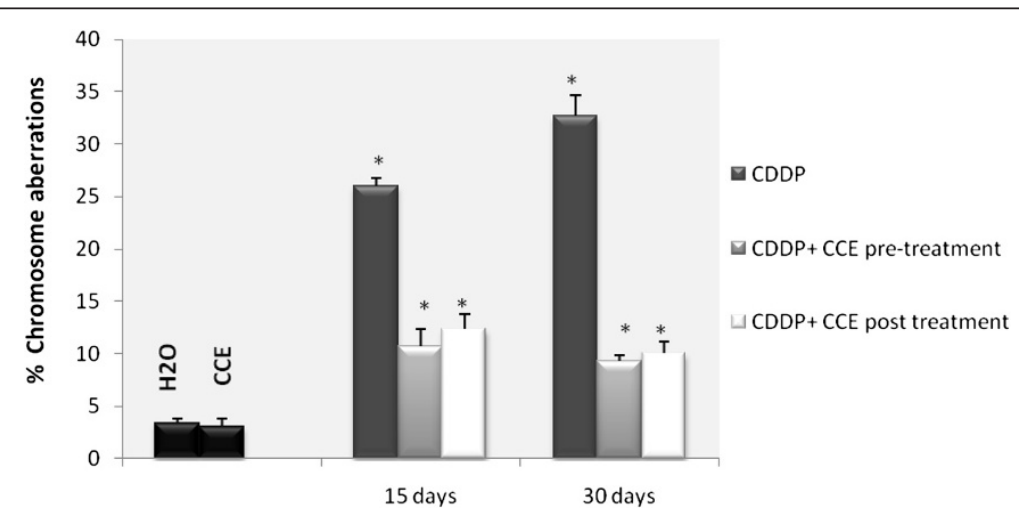

Figure 5 Effect of cactus cladodes on chromosomal aberrations in bone marrow cells of CDDP treated balb/c mice. * indicated significant difference $(p<0.05)$ from control. For 15 days of treatment: Mice given CDDP $100 \mu \mathrm{g} / \mathrm{Kg}$ b.w or Mice given CDDP $100 \mu \mathrm{g} / \mathrm{Kg}$ b.w + CCE $50 \mathrm{mg} / \mathrm{Kg}$ b.w (pre-treatment) and Mice given CDDP $100 \mathrm{\mu g} / \mathrm{Kg}$ b.w + CCE $50 \mathrm{mg} / \mathrm{Kg}$ b.w (post-treatment). For 30 days of treatment: Mice given CDDP $100 \mu \mathrm{g} / \mathrm{Kg}$ b.w or Mice given CDDP $100 \mu \mathrm{g} / \mathrm{Kg}$ b.w + CCE $50 \mathrm{mg} / \mathrm{Kg}$ b.w (pre-treatment) and Mice given CDDP $100 \mu \mathrm{mg} / \mathrm{Kg}$ b.w + CCE $50 \mathrm{mg} / \mathrm{Kg}$ b.w (post-treatment). 
Table 2 Genotoxic activity of cactus cladode extract and CDDP by the SOS chromotest in the presence of E.coli PQ37

\begin{tabular}{llll}
\hline Extract & $\boldsymbol{\beta}$-gal (U) & AP $(\mathbf{U})$ & IF \\
\hline NC & $0,65 \pm 0,001$ & $1,9 \pm 0,001$ & \\
\hline AFB1 & $9,21 \pm 0,005$ & $2,5 \pm 0,003$ & 4,24 \\
\hline CDDP & $1,98 \pm 0,004$ & $2,5 \pm 0,002$ & 3,24 \\
\hline CCE & $1,1 \pm 0,002$ & $1,7 \pm 0,001$ & 0,73 \\
\hline CDDP +CCE & $1,56 \pm 0,002$ & $1,25 \pm 0,002$ & 1,35
\end{tabular}

$\beta$-gal $\beta$-galactosidase, $A P$ alkaline phosphatase, $U$ enzyme units, IF induction factor, NC negative control (non treated cells). AFB1 aflatoxin B1. (Positive control of genotoxicity).

\section{Determination of bcl2 expression}

Figure $8 \mathrm{a}$ and $8 \mathrm{~b}$ shows the western blotting and densitometry analysis of bcl 2 expression in kidney of controls and treated animals. After 15 days and 30 days exposure to CDDP alone, anti-apoptotic protein bcl 2 expression was found to be significantly decreased by $60 \%$ after CDDP treatment compared to controls, but it increased before or after treatment by CCE. The CCE treated group did not have any significant effect on the expression of bcl2 (Additional file 1).

\section{Effect of CCE on CDDP-induced nephrotoxicity parameters in serum}

CCE alone had no effect on serum creatinine, urea, albumin and total protein. The administration of CDDP $(100 \mu \mathrm{g} / \mathrm{kg} \mathrm{bw})$ to mice caused significant increase in blood levels of creatinine and urea and decreased significantly blood levels of albumin and total protein. When CCE was given to CDDP mice, CDDP elicited nephrotoxic alterations appeared to be ameliorated. In fact,

(a)

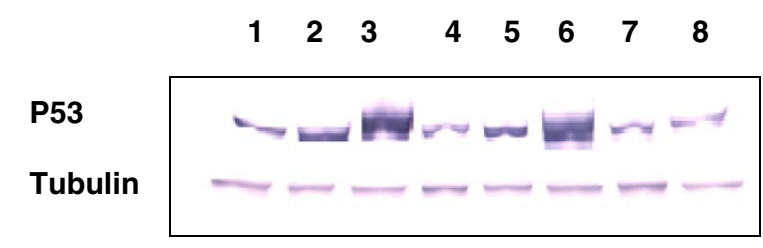

(b)

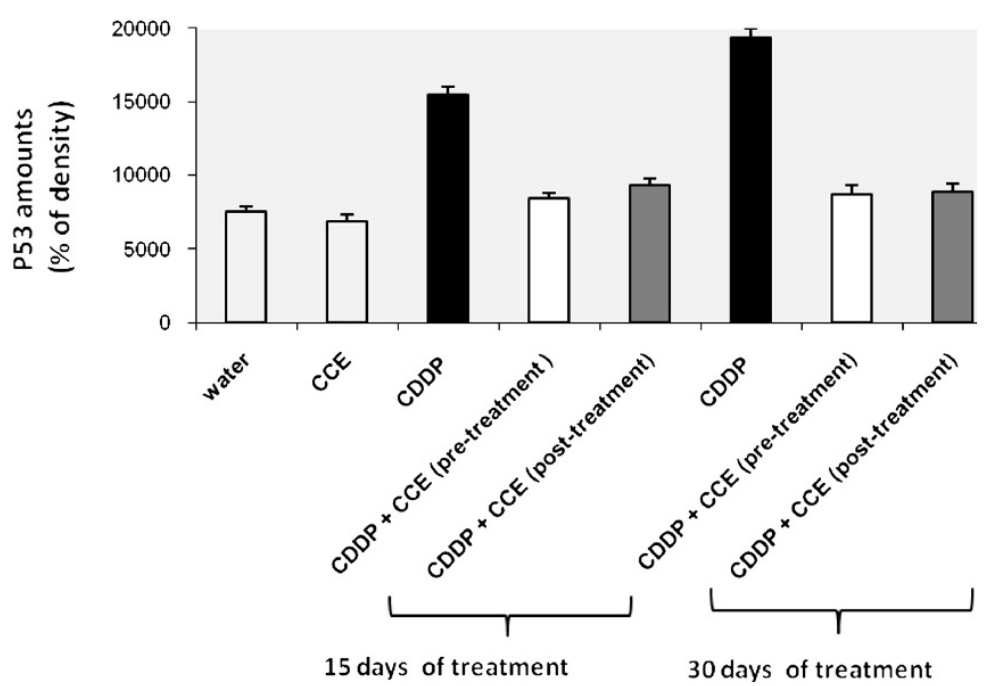

Figure 6 Immunoblot (a) and densitometric (b) analysis of p53 in kidney of control and treated animals. The protein was separated on 12\% SDS-PAGE and blotted with anti-p53 antibody. The intensity of the protein band was scanned by densitometry. Some modifications are made to blots by adjusting the luminosity and contrast of the protein bands to better understand the effects of CDDP and CCE (Unmodified versions of Western blot have been included as an Additional file 1: Figure S1). Results are significantly different as compared to controls ( $p<0.005$ ). The results are representative of eight independent experiments: (1) Animals treated by $100 \mu \mathrm{H} \mathrm{H}_{2} \mathrm{O}$ (2) Animals treated by CCE

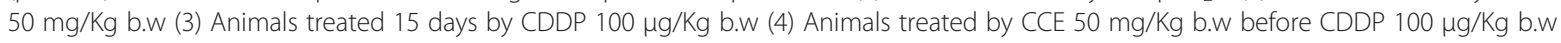
exposure for 15 days treatment (5) Animals treated by CCE $50 \mathrm{mg} / \mathrm{Kg}$ b.w after CDDP $100 \mathrm{\mu g} / \mathrm{Kg}$ b.w exposure for 15 days treatment (6) Animals treated 30 days by CDDP $100 \mu \mathrm{g} / \mathrm{Kg}$ b.w (7) Animals treated by CCE $50 \mathrm{mg} / \mathrm{Kg}$ b.w before CDDP $100 \mu \mathrm{g} / \mathrm{Kg}$ b.w exposure for 30 days treatment (8) Animals treated by CCE $50 \mathrm{mg} / \mathrm{Kg}$ b.w after CDDP $100 \mu \mathrm{g} / \mathrm{Kg}$ b.w exposure for 30 days treatment. 
(a)

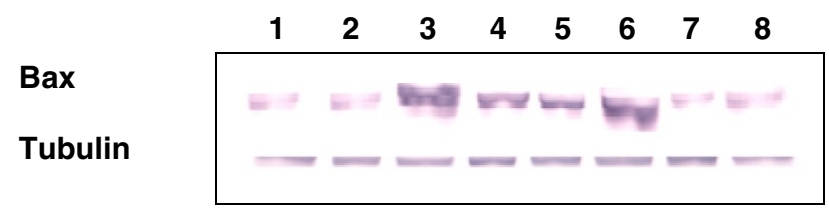

(b)

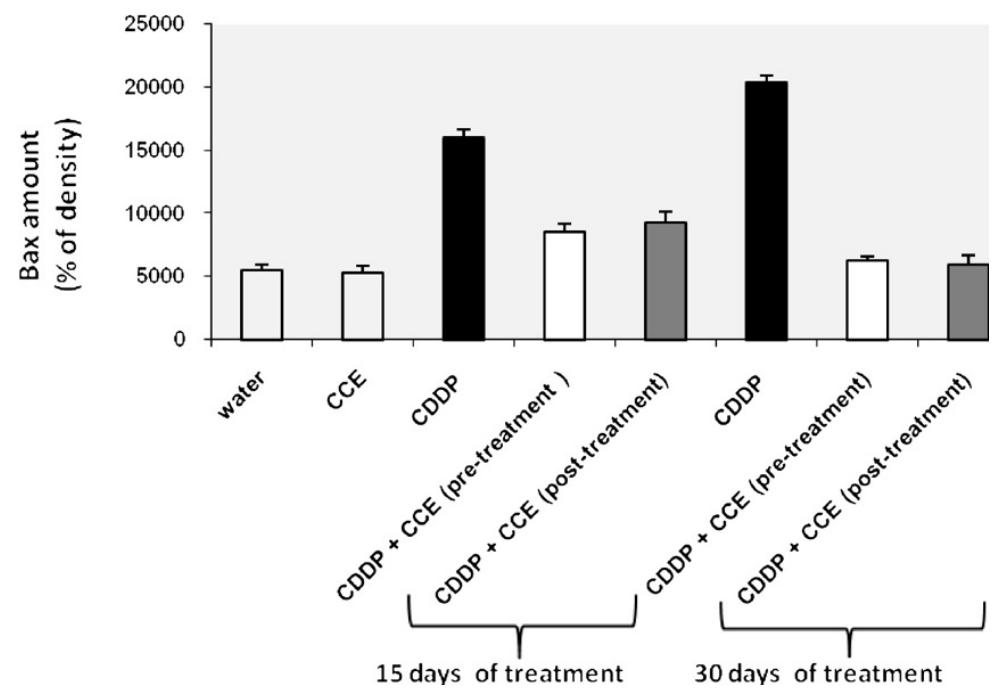

Figure 7 Immunoblot (a) and densitometric (b) analysis of bax in kidney of control and treated animals. The protein was separated on $12 \%$ SDS-PAGE and blotted with anti-bax antibody. The intensity of the protein band was scanned by densitometry. Results are significantly different as compared to controls $(\mathrm{p}<0.005)$. The results are representative of eight independent experiments: (1) Animals treated by $100 \mu \mathrm{H} \mathrm{H}_{2} \mathrm{O}$ (2) Animals treated by CCE $50 \mathrm{mg} / \mathrm{Kg}$ b.w (3) Animals treated 15 days by CDDP $100 \mu \mathrm{gg} / \mathrm{Kg}$ b.w (4) Animals treated by CCE $50 \mathrm{mg} / \mathrm{Kg}$ b.w before CDDP $100 \mu \mathrm{g} / \mathrm{Kg}$ b.w exposure for 15 days treatment (5) Animals treated by CCE $50 \mathrm{mg} / \mathrm{Kg}$ b.w after CDDP 100 mg/Kg b.w exposure for 15 days

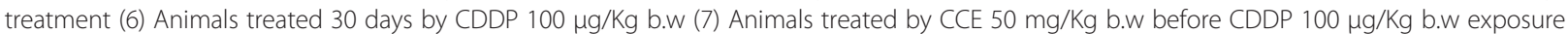
for 30 days treatment (8) Animals treated by CCE $50 \mathrm{mg} / \mathrm{Kg} \mathrm{b.w} \mathrm{after} \mathrm{CDDP} 100 \mu \mathrm{g} / \mathrm{Kg}$ b.w exposure for 30 days treatment.

additions of CCE with pre or post-treatment to CDDP mice seemed to restore serums levels of creatinine, urea, albumin and total protein resuming its values towards near normal levels of control (Table 3).

\section{Discussion}

CDDP is an extensively used anti-cancer agent for the management of germ cell tumors, head and neck cancers, bladder cancer, cervical cancer and as a salvage treatment for other solid tumors [32]. Although higher doses of CDDP are more efficacious for the suppression of cancer but high dose therapy manifests irreversible renal dysfunction [33] and damage to non-tumor cells. The concept of cancer and chronic kidney diseases prevention using naturally occurring substances that can be included in the diet consumed by the human population is gaining increasing attention. In this line, different types of fruits and vegetables have been re-evaluated and recognized as valuable sources of nutraceuticals.
Polyphenolic compounds are abundant in foods of plant origin. The application of such bioactive plant components may increase the stability of foods and, at the same time, improve their health properties associated with anti-cancer, antiallergic and anti-inflammatory activities of polyphenols in the human body [34-36].

The total polyphenol content of the cladode extracts from Opuntia ficus indica was expressed as gallic acid equivalents. The total flavonoids contents of the CCE is determined by using the method of Zhishen et al. (1999) [19] and expressed as quercetin equivalents [37,38]. Significantly high total polyphenols and flavonoids content of the CCE may be corroborated with the observed antioxidant and antigenotoxic activities (Table 1).

The present study was performed to test the hypothesis that CCE would ameliorate CDDP induced oxidative stress and genotoxicity causes of nephrotoxic effect allowing the clinical use of CDDP in the treatment of various malignancies and minimizing its side effects. To 
(a)

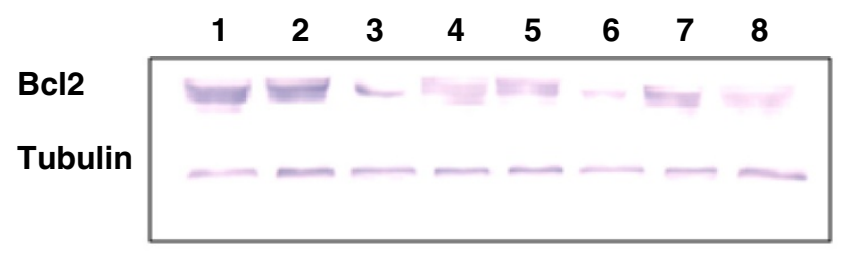

(b)

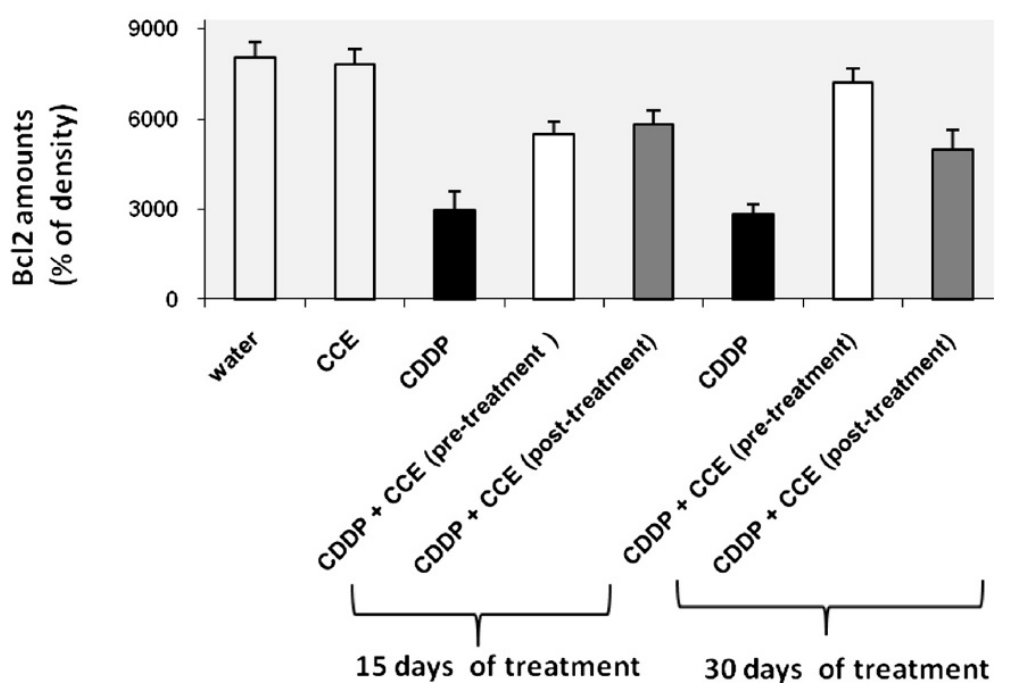

Figure 8 Immunoblot (a) and densitometric (b) analysis of bcl2 in kidney of control and treated animals. The protein was separated on $12 \%$ SDS-PAGE and blotted with anti-bcl2 antibody. The intensity of the protein band was scanned by densitometry. Some modifications are made to blots by adjusting the luminosity and contrast of the protein bands to better understand the effects of CDDP and CCE (Unmodified versions of Western blot have been included as an Additional file 1: Figure S1). Results are significantly different as compared to controls $(p<0.005)$. The results are representative of eight independent experiments: (1) Animals treated by $100 \mu \mathrm{l} \mathrm{H}_{2} \mathrm{O}$ (2) Animals treated by CCE

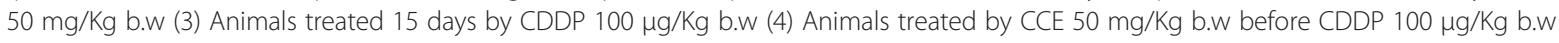
exposure for 15 days treatment (5) Animals treated by CCE $50 \mathrm{mg} / \mathrm{Kg}$ b.w after CDDP $100 \mathrm{\mu g} / \mathrm{Kg}$ b.w exposure for 15 days treatment (6) Animals treated 30 days by CDDP $100 \mu \mathrm{g} / \mathrm{Kg}$ b.w (7) Animals treated by CCE $50 \mathrm{mg} / \mathrm{Kg}$ b.w before CDDP $100 \mu \mathrm{g} / \mathrm{Kg}$ b.w exposure for 30 days treatment (8) Animals treated by CCE $50 \mathrm{mg} / \mathrm{Kg}$ b.w after CDDP $100 \mu \mathrm{g} / \mathrm{Kg}$ b.w exposure for 30 days treatment.

this end, we evaluated the effect of pre or posttreatment by CCE $50 \mathrm{mg} / \mathrm{kg}$ b.w in balb/c mice. The intraperitonial route for administration of the CCE in this dose was chosen based on reports in our studies which have shown that after testing several doses of cactus this dose is appropriate to induce a good prevention against oxidative stress induced by mycotoxine zearalenone in balb/c mice $[39,40]$.

To evaluate the oxidative status, we looked for an eventual lipid peroxidation which constitutes one of the most common indices used to assess oxidative stress. MDA is the end product of lipoperoxydation, considered as a late biomarker of oxidative stress and cellular damage [41,42]. In the present study, exposure to CDDP induces a marked increase in MDA formation in kidney but administration of CCE significantly reduced MDA level which dropped to the control level (Figure 2). Yuce et al. (2007) and
Al-Majed et al. (2006) [43,44] have also reported an increase in MDA and a decrease in the activities of antioxidant enzyme upon similar CDDP treatment of rats.

Also we looked for measured level of antioxidant enzymes catalase activity and SOD activity, were significantly $(\mathrm{p}<0.005)$ decreased compared to control (Figures 3 and 4); Yuce et al. (2007) [43] reported a similar decrease of antioxidant enzymes catalase and SOD by CDDP treatment in vivo. Also several investigators have demonstrated that CDDP induces ROS in renal epithelial cells primarily by decreasing the activity of antioxidant enzymes and by depleting intracellular concentrations of GSH, catalase and SOD activities [45,46]. The presence of CCE with CDDP by pre or post treatment normalized the levels of the antioxidant enzyme catalase and SOD to nearly the normal values of control. CCE ability to prevent and protect against oxidative 
Table 3 Effect of CCE on several serum parameters with/without CDDP treatment

\begin{tabular}{|c|c|c|c|c|c|c|c|c|}
\hline \multirow[t]{2}{*}{ Parameter } & \multicolumn{8}{|c|}{ Experimental groups } \\
\hline & Control & CCE & $\begin{array}{l}\text { CDDP } \\
15 \text { days }\end{array}$ & $\begin{array}{c}\mathrm{CDDP}+\mathrm{CCE} \\
\text { (pre-treatment) }\end{array}$ & $\begin{array}{c}\text { CDDP + CCE } \\
\text { (post-treatment) }\end{array}$ & $\begin{array}{l}\text { CDDP } \\
30 \text { days }\end{array}$ & $\begin{array}{c}\mathrm{CDDP}+\mathrm{CCE} \\
\text { (pre-treatment) }\end{array}$ & $\begin{array}{c}\text { CDDP + CCE } \\
\text { (post-treatment) }\end{array}$ \\
\hline Creatinine $(\mathrm{mg} / \mathrm{dl})$ & $0,8 \pm 0,14$ & $0,75 \pm 0,1$ & $1,79 \pm 0,0045^{*}$ & $0,56 \pm 0,005^{*}$ & $0,88 \pm 0,0048^{*}$ & $2,13 \pm 0,005^{*}$ & $0,87 \pm 0,0044$ & $0,95 \pm 0,0052$ \\
\hline Urea (mg/dl) & $52,34 \pm 0,12$ & $51,54 \pm 0,17$ & $79,13 \pm 0,12^{*}$ & $58,5 \pm 0,14^{*}$ & $60,13 \pm 0,19^{*}$ & $94,2 \pm 0,12^{*}$ & $60,12 \pm 0,18$ & $68,5 \pm 0,15$ \\
\hline Albumin $(\mathrm{g} / \mathrm{dl})$ & $10,44 \pm 0,14$ & $10,72 \pm 0,15$ & $8,01 \pm 0,17^{*}$ & $9,8 \pm 0,14^{*}$ & $8,48 \pm 0,18^{*}$ & $7,12 \pm 0,16^{*}$ & $9,91 \pm 0,12$ & $9,24 \pm 0,16$ \\
\hline Total protein $(\mathrm{g} / \mathrm{dl})$ & $9,95 \pm 0,19$ & $9,78 \pm 0,21$ & $7,12 \pm 0,25^{*}$ & $8,67 \pm 0,19^{*}$ & $8,03 \pm 0,26^{*}$ & $6,2 \pm 0,193^{*}$ & $8,7 \pm 0,23$ & $8,12 \pm 0,26$ \\
\hline
\end{tabular}

Experimental values are expressed as mean \pm SD. Comparison of mean values between groups was performed by one way-analysis of variance (oneway-ANOVA) $\left.{ }^{*}\right)$ significantly different from control at $\mathrm{p}<0.05$.

damage is certainly associated to the presence of several antioxidants such as ascorbic acid, flavonoids and phenolic acids actually detected in cladodes (Table 1 ) and in fruit [47-50].

Oxidative stress is important as direct and indirect initiator as well as promoter of genotoxicity and apoptotic process. The above genotoxic endpoints are well known markers of genotoxicity and any reduction in the frequency of these genotoxic endpoints gives an indication of the antigenotoxicity of a particular compound [51]. In addition, for the different studied genotoxic endpoints, the concentration of cactus $(50 \mathrm{mg} / \mathrm{kg}$ b.w.) was not genotoxic itself. In the current study, we tested the chromosomal aberrations assay which is widely used test to assess genotoxicity of chemicals. We have demonstrated that mice that received CDDP significantly increase the percentage of chromosome aberrations in bone marrow cells (Figure 5). The most frequent types of aberrations observed in the present study were chromosome breaks (Table 4), but gaps were also observed. Chromosome breaks were classified as chromatid or isochromatid. It is acknowledged that CDDP causes intrastrand and interstrand cross linking, probably between N7 and O6 of the adjacent guanine molecules, which results in local denaturation of the DNA chain [52]. Mice pre and post treated by CCE showed a significant reduction the percentage of chromosome aberrations in their bone marrow cells and the protection was around $50 \%$ and $70 \%$ respectively on 15 and
30 days treatment (Figure 4). The cytotoxic action of this drug is often thought to be associated with its ability to bind DNA to form CDDP-DNA adducts [53].

The absence of genotoxicity is not a characteristic of all natural products in use, since other medicinal plants, assayed with the SOS chromotest have resulted positively in genotoxicity [54]. These tests showed that CDDP present a genotoxic effect and that the treatment with CCE is able to remove this genotoxicity (Table 2).

The preliminary chemical study of CCE of Opuntia ficus indica, revealed the presence of important quantities of polyphenol compounds flavonoids and tannins in aqueous extracts. These results could be correlated to the antigenotoxic activity detected in this extract. In fact the CCE showed significant anti-genotoxicity towards CDDP. This suggests that CCE inhibit microsomal activation or that they directly protect DNA strands from the electrophilic metabolite of the mutagen. They may inhibit several metabolic intermediates and reactive oxygen species (ROS) formed during the process of microsomal enzyme activation which are capable of breaking DNA strands. Anti-genotoxic activity of CCE may be ascribed to flavonoids [55] and tannins [56,57] which are detected in our extract.

We cannot however, exclude the possibility that other compounds with anti-genotoxic properties, participate in the anti-genotoxic effect of CCE. On the other hand, CCE exhibited a significant antioxidant activity towards the free radical DPPH. These results were correlated

Table 4 Percentage of different type of chromosomal damage induced by CDDP and reversed with cactus cladodes extract before or after treatment with CDDP

\begin{tabular}{lcccrc}
\hline Experimental groups & Centric fusion & Ring & Break & Gap & Total \\
\hline H2O & $1,5 \pm 1,25$ & $1,00 \pm 0,43$ & $3,28 \pm 0,25$ & $0 \pm 0,00$ & $3,78 \pm 1,5$ \\
\hline CCE & $1,67 \pm 0,75$ & $1 \pm 1,33$ & $0 \pm 0,00$ & $1 \pm 0,67$ & $3,67 \pm 1,78$ \\
\hline CDDP 15 days & $2,13 \pm 0,28^{*}$ & $1 \pm 0,17$ & $10 \pm 2,02^{*}$ & $2,13 \pm 1,5^{*}$ & $15,26 \pm 1,75^{*}$ \\
\hline CDDP + CCE Pre-treatment & $1,66 \pm 0,55^{*}$ & $0 \pm 0,17$ & $6 \pm 1,68^{*}$ & $1 \pm 0,24$ & $8,66 \pm 1,53^{*}$ \\
\hline CDDP + CCE Post-treatment & $2,03 \pm 1,5^{*}$ & $1 \pm 0,33$ & $7,3 \pm 1,45^{*}$ & $0 \pm 0,00$ & $10,33 \pm 2,06^{*}$ \\
\hline CDDP 30 days & $5 \pm 1,77^{*}$ & $2,66 \pm 2,67^{*}$ & $20 \pm 1,57^{*}$ & $5 \pm 1,25^{*}$ & $32,66 \pm 2,14^{*}$ \\
\hline CDDP + CCE Pre-treatment & $3 \pm 1,48^{*}$ & $1,33 \pm 0,58^{*}$ & $5 \pm 2,01^{*}$ & $1 \pm 1,00^{*}$ & $10,33 \pm 1,45^{*}$ \\
\hline CDDP + CCE Post-treatment & $2 \pm 1,78^{*}$ & $1 \pm 0,25^{*}$ & $6 \pm 0,05^{*}$ & $3,58 \pm 1,45^{*}$ & $12,58 \pm 1,67^{*}$ \\
\hline
\end{tabular}

(*) Significant compared with group $1\left(\mathrm{H}_{2} \mathrm{O}\right)(\mathrm{P}<0.05)$. 
with the chemical composition of these extract. In fact, the chemical study of CCE, revealed the presence of important quantities of flavonoids. We believe that flavonoids are the most likely candidates among the compounds known to be present CCE for preventing oxidative lesions and providing antigenotoxic effect [58,59]. These compounds may inhibit free radicals and reactive oxygen species produced by CDDP.

The cytotoxicity of CDDP is believed to be due to the formation of DNA adducts, which include DNA-protein cross-links, DNA monoadducts, and interstrand and intrastrand DNA cross-links $[60,61]$. Further studies demonstrated that the cytotoxicity of CDDP is probably due to a combination of insults, including mitochondrial dysfunction [62], inhibition of protein synthesis [63] and DNA injury [64]. It has recently reported that DNA damage induced by CDDP leads to a rapid activation of ataxia telangiec- tasia and Rad3-related (ATR) which phosphorylates Chk2, a checkpoint kinase. ATR/Chk2 signaling is largely responsible for p53 phosphorylation and activation during CDDP treatment and the p53 protein binds DNA [65].

Many studies have now documented the rapid activation and nuclear translocation of p53 in response to CDDP both in kidneys [66] and in cultured renal proximal tubular cells [67]. It is well known that both CDDP-induced DNA damage and CDDP-induced oxidant stress are potent activators of p53 [68,69], and that p53 can in turn activate bax [70,71]. It is therefore likely that this regulatory mechanism may play a crucial role in CDDP-induced apoptosis.

In the present study, the modulatory effect of CCE on CDDP toxicity was suggested to carry out through alterations in cell death pathway, p53 and the ratio of $\mathrm{bax} / \mathrm{bcl}_{2}$ plays an important role in determining whether cells will undergo apoptosis. Our results showed that treatment by CDDP for 15 and 30 days induced high expressions of p53 and bax, an apoptotic marker in kidney tissues of CDDP treated mice than controls and down-regulation of antiapoptotic protein bcl2 (Figures 6a, 6b, 7a, 7b, 8a, 8b). Our study showed that the CCE treatment after or before CDDP treatment has been shown to induce an antiapoptotic effect via inhibition of p53 and bax expression (Figure 6a, 6b, 7a, 7b and 8a, 8b). This indicates that CCE modulates the p53 dependent apoptotic pathway to restrict the CDDP toxicity in kidneys.

Kidneys represent the major control system maintaining body homeostasis. The plasma concentrations of urea and creatinine determine renal function and are thus biomarkers for kidney disease [72]. Mice treated with $\mathrm{CCE}$ alone showed no significant change in the levels of urea and creatinine compared to control. While, CDDP treatment caused significant increase $(\mathrm{p}<0.05)$ in levels of both parameters accompanied by significant decrease in blood levels of albumin and total protein. The serum albumin concentration may be directly altered, as results to loss albumin through damaged glomeruli in case of renal failure [72]. Consequently, in the present study, the significant decrease in albumin may be evidence on CDDP-induced nephrotoxicity. Mice exposed to CCE before or after CDDP exhibited a significant $(p<0.05)$ decrease in the levels of urea and creatinine and increase levels of albumin and total protein; in fact, CCE seemed to restore serums levels of creatinine, urea, albumin and total protein resuming its values towards near normal levels of control (Table 3). The increase in both urea and creatinine levels due to CDDP treatment has been previously reported by Shemida et al. (2005), Iseri et al. (2007) and Mansour et al. (2002) [73-75]. Nephrotoxic damage by CDDP is indicated by increase in blood urea and creatinine levels. Excretion of CDDP is predominantly renal, and the kidney is considered to be the primary target organ for CDDP toxicity. Consequently, the impairment of kidney function by CDDP is recognized as the main side effect and the dose limiting factor associated with its use, occurring either acutely or after repeated treatment [76].

Total protein concentration is likely to be decreased if there is inhibition of protein synthesis or if degradation of protein is promoting [77]. CDDP diminishes DNA, RNA and protein synthesis. Ribosomal DNA accumulates CDDP-induced DNA adducts. This is consistent with the CDDP- induced injury. Moreover, CDDPinduced transcription highjacking is another reason for the inhibition of protein synthesis associated with CDDP. Transcription highjacking refers to the consequences of the ability of certain transcription factors to bind to DNA adducts caused by organoplatinum compounds. This leads to the sequestration of these transcription factors from their usual promoter binding sites [78].

\section{Conclusion}

In agents in the treatment of cancer. In spite of its clinical usefulness, there are many occasions in which it is difficult to continue the administration of the drug due to its nephrotoxicity. In the present study, it is clear that CDDP exposure resulted oxidative stress, genomic DNA damage, apoptotic cell death in kidney, increased serum creatinine and blood urea, and decreased levels of albumin and total protein biomarkers for kidney disease. But CCE exposure prior and post to CDDP provided near complete protection in terms of generation of oxidative stress, genomic DNA integrity and modulate apoptosis status. According to our results we noticed a similar effect between the pre and post treatment for the antioxidant and antigenotoxic effects of CCE. Our results 
indicate that antioxidant of CCE would support biological resistance to free radicals, suggesting the capacity of this extract to play a role in antigenotoxic, antiapoptotic and anti-nephrotoxic effects of CCE. The protective effect of CCE makes them promising candidates for further studies designed to obtain more evidence on their components with potential chemo-preventive activity.

\section{Additional file}

Additional file 1: Figure S1. Unmodified versions of Immunoblot of $\mathrm{p} 53$, bax and $\mathrm{bcl}_{2}$ in kidney of control and treated animals. The protein was separated on 12\% SDS-PAGE and blotted with anti-p53 antibody, anti-bax antibody and anti-bcl 2 antibody.

\section{Competing interests}

The authors declare that they have no competing interest.

\section{Authors' contributions}

DB carried out the studies, acquired the data, performed the data analysis, and drafted the manuscript. YA played a major role in the experimental procedures of this study and revised the manuscript. MH has a role in the achievement of radical scavenging activity test. $\mathrm{HbM}$ carried out the part of genotoxicity tests; LZ carried out statistical analysis; $\mathrm{HB}$ and $\mathrm{CB}$ involved in the design and organization of the study, interpreted the results and revised the manuscript. All authors have read and approved the final manuscript.

\section{Acknowledgements}

This research was funded by the Tunisian Ministry of Scientific Research and Technology through the Laboratory for Research on Biologically Compatible Compounds (LRSBC), Faculty of Dentistry of Monastir and the Research Unit of Macromolecular Biochemistry and Genetics (BMG), Faculty of Sciences of Gafsa.

\section{Author details}

'Laboratory of Research on Biologically Compatible Compounds, Faculty of Dentistry, Rue Avicenne, 5019, Monastir, Tunisia. ${ }^{2}$ Research unit of Macromolecular Biochemistry \& Genetic, Faculty of Sciences Gafsa, Gafsa 2112, Tunisia. ${ }^{3}$ Laboratory of Cellular and Molecular Biology, Faculty of Dental Medicine, University of Monastir, Rue Avicenne, Monastir 5000, Tunisia. ${ }^{4}$ Higher Institute of Applied Biology ISBAM Medenine, University of Gabes, Gabes, Tunisia. ${ }^{5}$ University of Jendouba, Jendouba, Tunisia.

Received: 18 August 2011 Accepted: 21 June 2012

Published: 31 July 2012

\section{References}

1. Thigpen T, Vance R, Puneky L, Khansurt T: Chemotherapy in advanced ovarian carcinoma: current standard of care based on randomized trials. Gynecological Oncology 1994, 55:597-607.

2. Tikoo K, Bhatt DK, Gaikawad AB, Sharma V, Kabra DG: Differential effects of tannic acid on cisplatin induced nephrotoxicity in rats. FEBS Lett 2007, 581:2027-2035.

3. Ajith TA, Usha S, Nivitha V: Ascorbic acid and a-tocopherol protect anticancer drug cisplatin induced nephrotoxicity in mice. A comparative study. Clin Chim Acta 2007, 375:82-86.

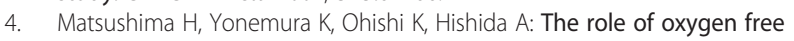
radicals in cisplatin-induced acute renal failure in rats. $J \mathrm{Lab}$ Clin Med 1998, 131:518-526.

5. Lieberthal W, Triaca V, Levine J: Mechanisms of death induced by cisplatin in proximal tubular epithelial cells: apoptosis vs. necrosis. AJP 1996, 270:F700-F708.

6. Badary OA, Abdel-Maksoud S, Ahmed WA, Owieda GH: Naringenin attenuates cisplatin nephrotoxicity in rats. Life Sci 2005, 76:2125-2135.

7. Ishikawa M, Takayanagi Y, Sasaki K: Enhancement of cisplatin toxicity by buthionine sulfoximine, a glutathionedepleting agent, in mice. Res Comm Chem Pathol Pharmacol 1990, 67:131-141.
8. Uslu R, Bonavida B: Involvement of the mitochondrion respiratory chain in the synergy achieved by treatment of human ovarian carcinoma cell lines with both tumor necrosis factor-alpha and cis diamminedichloroplatinum. Cancer 1996, 77:725-732.

9. Ali BH, Al Moundhri SM: Agents ameliorating or augmenting the nephrotoxicity of cisplatin and other platinum compounds: a review of some recent research. Food Chem Toxicol 2006, 44:1173-1183.

10. Alschuler L: Green tea: healing tonic. Am J Nat Med 1998, 5:28-31.

11. Connor WE: Importance of n-3 fatty acids in health and disease. Am J Clin Nutr 2000, 71:171S-175S.

12. Stintzing FC, Herbach KM, Mosshammer MR, Carle R, Yi WG, Sellappan S, Akoh R, Bunch CC, Felke P: Color, betalain pattern, and antioxidant properties of cactus pear (Opuntia spp.) clones. J Agric Food Chem 2005, 53:442-451.

13. Zou DM, Brewer M, Garcia F, Feugang JM, Wang J, Zang R, Liu H, Zou C: Cactus pear: natural product in cancer chemoprevention. Nutr J 2005, 4:25-36.

14. Agozzino P, Avellone G, Caraulo L, Ferrugia M, Flizzola F: Volatile profile of Sicilian prickly pear (Opuntia ficus-indica) by SPME-GC/MS analysis. Ital J Food Sci 2005, 17:341-348.

15. Galati EM, Mondello MR, Giuffrida D, Dugo G, Miceli N, Pergolizzi S, Taviano MF: Chemical characterization and biological effects of Sicilian Opuntia ficus indica (L.) Mill. fruit juice: antioxidant and antiulcerogenic activity. J Agric Food Chem 2003, 51:4903-4908.

16. Dok-Go H, Lee KH, Kim HJ, Lee EH, Lee J, Song YS, Lee Y-H, Jin C, Lee YS, Cho J: Neuroprotective effects of antioxidative flavonoids, quercetin, (+)- dihydroquercetin and quercetin 3-methyl ether, isolated from Opuntia ficus indica var.saboten. Brain Res 2003, 965:130-136.

17. Yuan VY, Bone DE, Carrington F: Antioxidant activity of dulse (Palmaria palmata) extract evaluated in vitro. Food Chem 2005, 91:485-494.

18. Kumar A, Chattopadhyay S: DNA damage protecting activity and antioxidant potential of pudina extract. Food Chem 2006, 100:1377-1384.

19. Zhishen J, Mengcheng T, Jianming W: The determination of flavonoid contents in mulberry and their scavenging effects on superoxide radicals. Food Chem 1999, 64:555-559.

20. Pearson D: The Chemical Analysis of Foods. 7th edition. London: Churchill Livingstone; 1976:572.

21. Nwabueze TU: Effect of process variables on trypsin inhibitor activity (TIA) phytic acid and tannin content of extruded African breadfruit-cornsoy mixtures: a response surface analysis. Lebensm Wiss Technol 2007, 40:21-29.

22. Blois MS: Antioxidant determination by the use of a stable free radical. Nature 1958, 181:1199-1200.

23. Aust SD, Morehouse LA, Thomas CE: Role of metals in oxygen radical reactions. J Free Radic Biol Med 1985, 1:3-25.

24. Claiborne A: Catalase activity. In Handbook of methods for oxygen research Edited by Greenwald RA. Boca Raton, Fla: CRC Press; 1985:283-284.

25. Sun Y, Oberley LW, Li Y: A simple method for clinical assay of superoxide dismutase. Clin Chem 1988, 34:497-500.

26. Evans $E P$, Breckon G, Ford CE: An air drying method for meiotic preparation from mammalian tests. Cytogenet 1960, 3:613-616.

27. Savage JRK: Classification and relationships of induced chromosomal structural changes. J Med Genet 1975, 12:103-122.

28. Maron DM, Ames BN: Revised methods for the Salmonella mutagenicity test. Mutat Res 1983, 113:173-215.

29. Quillardet $P$, Hofnung M: The SOS Chromotest, a colorimetric bacterial assay for genotoxins: procedures. Mutat Res 1985, 147:65-78.

30. Gornall AG, Bardwill CS, David MM: Determination of serum proteins by means of biuret reaction. J Biol Chem 1949, 177:751-766.

31. Doumas B, Tn Watson WA, Biggs HG: Albumin standards and measurement of serum albumin with bromocresol green. Clinica Chimica Acta 1977, 31:87-96.

32. Chester JD, Hall GD, Forster M, Protheroe AS: Systemic chemotherapy for patients with bladder cancer-current controversies and future directions. Cancer Treat Rev 2004, 30:343-358.

33. Taguchi T, Nazneen A, Abid MR, Razzaque MS: Cisplatin associated nephrotoxicity and pathological events. Contrib Nephrol 2005, 148:107-121.

34. Moure A, Jose M, Cruz D, Franco M, Domínguez J, Sineiro J, Domínguez H, Núñez MJ, Parajó JC: Natural antioxidants from residual sources. Food Chem 2001, 72:145-171. 
35. Rice-Evans CA, Miller NJ, Paganga G: Structure antioxidant activity relationships of flavonoids and phenolic acids. Free Radic Biol Med 1996, 20:933-956

36. Capecka E, Mareczek A, Leja M: Antioxidant activity of fresh and dry herbs of some Lamiaceae species. Food Chem 2005, 93:223-226.

37. Luximon-Ramma A, Bahorun T, Soobrattee MA, Aruoma O: Antioxidant activities of phenolic, proanthocyanidin, and flavonoid components in extract of Cassia fistula. J Agric Food Chem 2002, 50(18):5042-5047.

38. Eberhardt MV, Lee CY, Liu RH: Antioxidant activity of fresh apples. Nature 2000, 405:903-904

39. Zourgui L, Ayed-Boussema I, Ayed Y, Bacha H, Hassen W: The antigenotoxic activities of Cactus (Opuntia ficus indica) cladodes against the mycotoxin zearalenone in Balb/c mice Prevention of micronuclei, chromosome aberrations and DNA fragmentation. Food Chem Toxicol 2009, 47:662-667.

40. Zourgui L, Golli EE, Bouaziz C, Bacha H, Hassen W: Cactus (Opuntia ficus indica) Cladodes prevent oxidative damage induced by the mycotoxin zearalenone in Balb/c mice. Food Chem Toxicol 2008, 46:1817-1824.

41. Kim HS, Kwack SJ, Lee BM: Lipid peroxidation, antioxidant enzymes, and benzo[a]pyrene-quinones in the blood of rats treated with benzo[a] pyrene. Chem Biol Interact 2000, 127:139-150.

42. Dotan Y, Lichtenberg D, Pinchuk I: Lipid peroxidation cannot be used as a universal criterion of oxidative stress. Prog Lipid Res 2004, 43:200-227.

43. Yuce A, Ates s ahin A, Ceribas AO, Aksakal M: Ellagic acid prevents cisplatin-induced Oxidative stress in liver and heart tissue of rats. Basic Clin Pharmacol Toxicol 2007, 101:345-349.

44. Al-Majed AA, Sayed-Ahmed AA, Al-Yahya AA, Aleisa AM, Al-Rejaie SS, Al Shabanah OA: Propionyl-I-carnitine prevents the progression of cisplatin induced cardiomyopathy in a carnitine-depleted rat model. Pharmacol Res 2006, 3:278-286

45. Husain K, Morris C, Whitworth C, Trammell GL, Rybak LP: Somani SM Protection by ebselen against cisplatin-induced nephrotoxicity: antioxidant system. Mol Cell Biochem 1998, 178:127-133.

46. Huang Q, Dunn RT, Jayadev S, DiSorbo O, Pack FD, Farr SB, Stoll RE, Blanchard KT: Assessment of cisplatin-induced nephrotoxocity by microarray technology. Toxicol Sci 2001, 63:196-207.

47. Kuti JO: Antioxidant compounds from four Opuntia cactus pear fruit varieties. Food Chem 2004, 85:527-533.

48. Tesoriere L, Fazzari M, Allegra M, Livrea MA: Biothiols, taurine, and lipidsoluble antioxidants in the edible pulp of Sicilian cactus pear (Opuntia ficus-indica) fruits and changes of bioactive juice components upon industrial processing. J Agric Food Chem 2005, 20:7851-7855.

49. Panico AM, Cardile V, Garufi F, Puglia C, Bonina F, Ronsisvalle G: Protective effects of Capparis spinosa on chondrocytes. Life Sci 2005, 77:2479-2488

50. Shim HC, Hwang HJ, Kang KJ, Lee BH: An antioxidative and anti inflammatory Agent for potential treatment of osteoarthritis from Ecklonia cava. Arch Pharm Res 2006, 29:165-171.

51. Albertini RJ, Ardell SK, Judice SA, Jacobson S, Allegretta M: Hypoxanthineguanine phosphoribosyltransferase reporter gene mutation for analysis of in vivo clonal amplification in patients with HTLV type 1-associated Myelopathy/Tropical spastic paraparesis. AIDS Res Hum Retroviruses 2000, 16:1747-1752.

52. Jamieson ER: Lippard SJ Structure, recognition, and proces- sing of cisplatin-DNA adducts. Chem Rev 1999, 99:2467-2498.

53. Goldstein RS, Mayor GH: The nephrotoxocity of cisplatin. Life Sci 1983, 32:685-690.

54. De Carvalho MCRD, Barca FNTV, Agnez-Lima LF, de Medeiros SRB: Evaluation of mutagenic activity in an extract of pepper tree stem barks (Schinus terebinthifolius Raddi). Environ Mol Mutagen 2003, 42:185-191.

55. Calomme M, Pieters L, Vlietink A, Berghe DV: Inhibition of bacterial mutagenesis flavonoids. Planta Med 1996, 92:222-226.

56. Lee KT, Sohn IC, Park HJ, Kim DW, Jung GO, Park KY: Essential moiety of antimutagenic and cytotoxic activity of hederagenin monodesmosides and bidesmosides isolated from the stem bark of Kalapanox pictus. Planta Med 2000, 66:329-332.

57. Baratto MC, Tattini M, Galardi C, Pinelli P, Romani A, Visioli F, Basosi R, Pongim R: Antioxidant activity of galloyl quinic derivatives isolated from P.lentiscus leaves. Free Radical Res 2003, 37:405-412

58. Edenharder $R$, Grunhage D: Free radical scavenging abilities of flavonoids as mechanism of protection against mutagenicity induced by tertbutyl hydroperoxide or cumene hydroperoxide in Salmonella typhimurium TA102. Mutat Res 2003, 540:1-18.

59. Park KY, Jung GO, Lee KT, Choi J, Choi MY, Kim GT, Jung HJ, Park HJ: Antimutagenic activity of flavonoids from the heartwood of Rhus verniciflua. J Ethnopharmacol 2004, 90:73-79.

60. Eastman A: Reevaluation of interaction of cis-dichloro(ethylenediamine) platinum(II) with DNA. Biochemistry 1986, 25:3912-3915.

61. Ingber DE: Cellular tensegrity: defining new rules of biological design that govern the cytoskeleton. J Cell Sci 1993, 104:613-627.

62. Brady HR, Kone BC, Stromski ME, Zeidel ML, Giebisch G, Gullans SR: Mitochondrial injury: an early event in cisplatin toxicity to renal proximal tubules. Am J Physiol 1990, 258:F1181-F1187.

63. Leibbrandt MEI, Wolfgang GHI, Metz AL, Ozobia AA, Haskins JR: Critical subcellular targets of cisplatin and related platinum analogs in rat renal proximal tubule cells. Kidney Int 1995, 48:761-770.

64. Kharbanda S, Ren R, Pandey P, Shafman TD, Feller SM, Weichselbaum RR, Kufe DW: Activation of the c-Abl tyrosine kinase in the stress response to DNA-damaging agents. Nature 1995, 376:785-788.

65. Pabla N, Huang S, Mi QS, Daniel R, Dong Z: ATR-Chk2 signaling in p53 activation and DNAdamage response during cisplatin-induced apoptosis. J Biol Chem 2008, 283:6572-6583. 6572.

66. Miyaji T, Kato A, Yasuda H, Fujigaki Y, Hishida A: Role of the increase in p21 in cisplatin-induced acute renal failure in rats. J Am Soc Nephrol 2001, 12:900-908.

67. Cummings BS, Schnellmann RG: Cisplatin-induced renal cell apoptosis: caspase 3-dependent and -independent pathways. J Pharmacol Exp Ther 2002, 302:8-17.

68. Muller M, Wilder S, Bannasch D, Israeli D, Lehlbach K, Li-Weber M, Friedman SL, Galle PR, Stremmel W, Oren M, Krammer PH: P53 activates the CD95 (APO-1/Fas) gene in response to DNA damage by anticancer drugs. J Exp Med 1998, 188:2033-2045.

69. Chandel NS, Vander Heiden MG, Thompson CB, Schumaker PT: Redox regulation of p53 during hypoxia. Oncogene 2000, 19:3840-3848.

70. Miyashita H, Nitta Y, Mori S, Kanzaki A, Nakayama K, Terada K, Sugiyama T, Kawamura H, Sato A, Morikawa H, Motegi K, Takebayashi Y: Expression of copper-transporting P-type adenosine triphosphatase (ATP7B) as a chemoresistance marker in human oral squamous cell carcinoma treated with cisplatin. Oral Oncol 2003, 39:157-162.

71. Burns TF, El-Deiry WS: The p53 pathway and apoptosis. J Cell Physiol 1999, 181:231-239.

72. Venkatesan N, Punithavathi D, Arumugam V: Curcumin prevents adriamycin nephrotoxicity in rats Brit. J Pharmacol 2000, 129:231-234.

73. Shemida Y, Hirotani Y, Akimoto YS, Ahindou K, ljiri Y, Nishihori T, Tanaka K: Protective effects of capsaicin against cisplatin-induced nephrotoxicity in rats. Biol Pharm Bull 2005, 28:1635-1638.

74. Iseri S, Ercan F, Gedik N, Yuksel M, Alican I: Simvastatin attenuates cisplatin-induced kidney and liver damage in rats. Toxicology 2007, 230:256-264.

75. Mansour MA, Mostafa AM, Nagi MN, Khattab MM, Al-Shabanah OA: Protective effect of aminoguanidine against nephrotoxicity induced by cisplatin in normal rats. Comp Biochem Physiol Toxicol Pharmacol 2002, 2:123-128.

76. Saad SY, Al-Rikabi AC: Protection effects of taurine supplementation against cisplatin-induced nephrotoxicity in rats. Chemotherapy 2002, 48:42-48.

77. Heidenreich O, Neininger A, Schratt G, Zinck R, Cahill MA, Engel K: MAPKAP kinase 2 phosphorylates serum response factor in vitro and in vivo. $J$ Biol Chem 1999, 274:14434-14443.

78. Tarloff J, Lash L: Toxicology of the Kidney. 3rd edition. Boca Raton: CRC Press; 2004

doi:10.1186/1472-6882-12-111

Cite this article as: Brahmi et al:: Protective effect of cactus cladode extract against cisplatin induced oxidative stress, genotoxicity and apoptosis in balb/c mice: combination with phytochemical composition. BMC Complementary and Alternative Medicine 2012 12:111. 